\title{
Geomechanical analysis of the rock mass stability in the area of the "Regis" shaft in the "Wieliczka" salt mine
}

\author{
Grzegorz Dyduch, Patrycja Jarczyk \& Marek Jendryś \\ Silesian University of Technology, Gliwice, Poland
}

\begin{abstract}
SUMMARY: The "Regis" shaft is one of the key workings which ensure the safety and smooth flow of tourist traffic in the historic Wieliczka salt mine. Its fault-free operation requires the monitoring of the technical condition of the supports and the surrounding rock mass. The results of the conducted monitoring and macroscopic observations of the lining in the shaft and of the adjacent workings have exhibited gradual and progressive degradation of the rock mass structure. In order to assess the impact of these processes on the shaft and on the nearby workings, a spatial numerical model of the rock mass has been created using the FLAC 3D software. The model geometry was determined after analysing the geological documentation of the area in the form of maps, cross-sections, and on the basis of visitations in the workings located in the vicinity of the shaft. On this basis, it was determined that the behaviour of the "Regis" shaft is primarily affected by a large post-mining chamber (the "Kloski" chamber) located in its immediate vicinity, on the north-eastern side. The tool used for the simulation (FLAC 3D software) allowed for the mapping of the behaviour of the continuous medium and the simulation of the destruction of the material by assigning to it (after reaching the limit stress state) the features of a plastic medium. On the basis of conducted calculations and simulations, it was determined that leaving the rock mass without any protective works may pose a threat to its stability and the stability of the "Regis" shaft lining. To protect the shaft and the rock mass, it was proposed to fill the "Kloski" chamber and the shaft below level IV. Such solution would stop the propagation of damage zones and minimise the rock mass displacement. Creating a stress and deformation state in the model, achieved as a result of backfilling a part of the shaft and the chamber, is highly likely to ensure the stability and safe operation of the workings located above it, in particular the section of the "Regis" shaft from the surface to level IV. The presented example showing, that backfilling used even many years after excavation of chamber can bring good results in terms of improving rock mass stability.
\end{abstract}

Keywords: backfill, numerical modelling, rock mass, shaft

\section{INTRODUCTION}

Safe exploitation and the possibility of making workings in historic underground mines available for tourist traffic require preserving their ongoing stability. This is particularly important in the case of development workings, which not only perform transport and ventilation functions, but also act as key evacuation routes. Any damage to their supports can constitute a serious threat to the operation of an entire mine. Workings of this type include the "Regis" shaft of the Wieliczka salt mine, currently acting as the main transportation shaft for the tourist traffic. Its history dates back to the fourteenth century. As a working providing access to the further parts of the deposit, it was maintained for several hundred years, performing mainly mining and ventilation functions. The exploitation of salt deposits carried out at that time in the immediate 
vicinity of the shaft caused irreversible changes to the rock mass structure. Their impact on the shaft tube, rock mass, and terrain surface, despite the cessation of exploitation, is also currently observed in the form of progressive deformations (Kwinta 2012; Bruneau et al. 2003; Tajduś et al. 2003; Majcherczyk and Lubryka 2003). The rheological processes taking place in the rock mass may be associated with a large volume of the deposit exploited in the vicinity of the "Regis" shaft. Post-exploitation voids have only been partially liquidated, which means that they continue to significantly affect the behaviour of the rock mass around the shaft tube. An additional factor adversely affecting the condition of the rock mass in the vicinity of the "Regis" shaft is the presence of unexploited salt blocks in its profile, which, due to rheological processes, increase the load on the lining (Chudek et al. 200; Kortas 2010).

Due to the complexity of the issue, geomechanical analyses of the rock mass are usually performed using methods based on numerical modelling. Due to the relatively high degree of complexity of the geomechanical conditions in the vicinity of the "Regis" shaft, the FLAC 3D software based on the finite difference method has been used to perform the analysis. The selection of the mode of analysis is dictated by the confirmed effectiveness of this method, which has already been repeatedly employed to assess the condition of the rock mass and workings at the Wieliczka salt mine, as evidenced by the publications on this subject (Cała et al. 2009; Cieślik et al. 2009; Cała et al. 2016).

\section{NUMERICAL SIMULATIONS OF THE ROCK MASS BEHAVIOUR IN THE VICINITY OF THE "REGIS” SHAFT}

\subsection{Model structure}

In order to map the stress and deformation states in the rock mass, a spatial numerical model has been created which incorporated the rectangular rock mass with the centrally located "Regis" shaft. The model geometry was determined after analysing the geological documentation of the area in concern in the form of maps, cross-sections, and on the basis of visitations in workings located in the vicinity of the shaft in concern. On this basis, it was determined that the behaviour of the "Regis" shaft is primarily affected by a large post-mining chamber (the "Kloski" chamber) with varying degrees of filling, located in its immediate vicinity, on the north-eastern side.

The performed numerical simulations allowed for the determination of stress and deformation changes in the rock mass surrounding the "Regis" shaft. As a result of the redistribution of primary stresses existing in the rock mass before the shaft and its adjacent chambers were created, a secondary state of equilibrium was achieved, characterised by stress concentration zones, occurrence of stress relief zones, and local zones where the rock mass reached a postcritical state. The tool used for the simulation (FLAC 3D software) allowed for the mapping of the behaviour of the continuous medium and for the simulation of the destruction of the material by assigning to it (after reaching the limit stress state) the features of a plastic medium.

Hence, the main indicator adopted for assessing the state of the rock mass in this paper are displacements and plasticisation zones where the material was damaged. In the real rock mass, this may result in its fracturing, spalling of the mass, and formation of collapses. Such manner of assessing the state of the rock mass was also used in papers concerning shafts (Wang et al. 2003, Kleta and Jendryś 2013).

The state of the rock mass can also be assessed on the basis of the effort indicator (D'Obryn and Wiewiórka 2015) or through the stability indicator, determined using the shear strength reduction method (Cała et al. 2009).

The modelled rock mass in the horizontal plane exhibited dimensions of $400 \times 400 \mathrm{~m}$, at a depth of $300 \mathrm{~m}$, as shown in Figure 1. The following rock formations were mapped in the model based on the geological documentation of the analysed area:

- marly claystone covering the largest part of the model, from its bottom wall to a depth of $28 \mathrm{~m}$,

- argillous-gypsum buffer zone with a thickness of $20 \mathrm{~m}$ occurring directly above the marly claystone,

- quaternary sediments with a thickness of $8 \mathrm{~m}$, constituting the upper part of the model. 


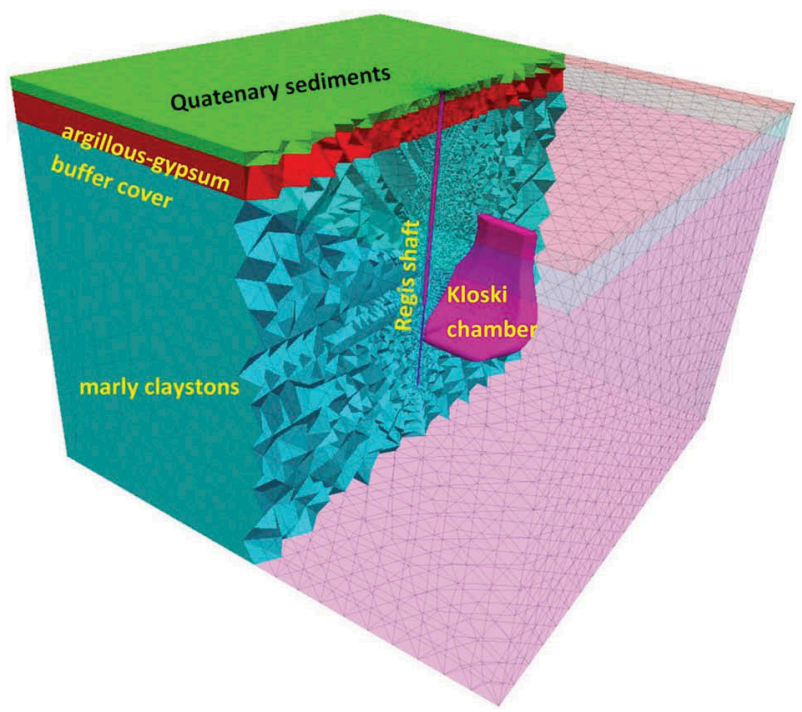

Figure 1. The geometry of the numerical model adopted for calculations.

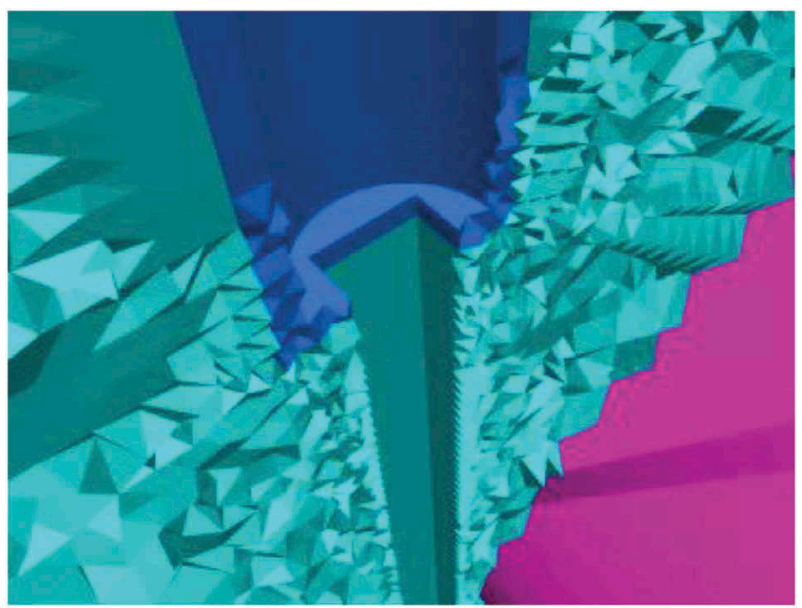

Figure 2. The model geometry in the shaft bottom zone of level IV.

The shaft was modelled in two sections with varying cross-sections (Figure 2), i.e.:

- from the surface to a depth of $170 \mathrm{~m}$ (down to level IV), a circular shaft was modelled with a diameter of $5.0 \mathrm{~m}$ and a lining thickness of $0.8 \mathrm{~m}$. For the elements constituting the lining, a material corresponding to $\mathrm{C} 20 / 25$ concrete class was adopted,

- from a depth of $170 \mathrm{~m}$ a shaft was modelled with a $4 \times 4 \mathrm{~m}$ square section from the material corresponding to the parameters of the existing wooden supports.

To the north-east of the "Regis" shaft, the post-mining void, called the "Kloski" chamber, was modelled, with a geometry that was adopted on the basis of a vertical cross-section and maps of individual levels (Figure 3).

In the model, displacement boundary conditions were adopted in the form of supports preventing the movement of the nodes located on the outer walls of the model in perpendicular 


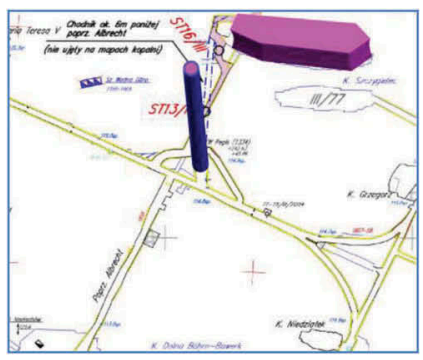

LEVEL III, $+114.68 \mathrm{M}$

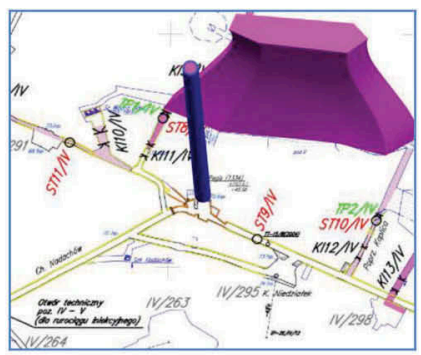

LEVEL IV, $+72.42 \mathrm{M}$

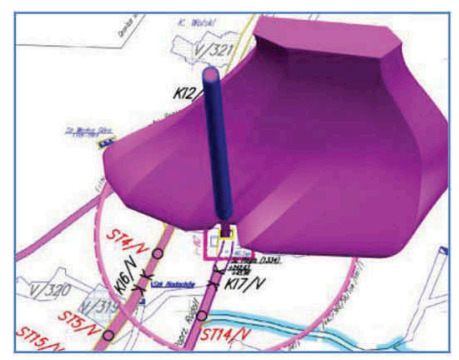

LEVEL V, +46.19 M

Figure 3. The "Kloski" chamber geometry in relation to the maps of individual levels.

Table 1. Summary of adopted material parameters.

\begin{tabular}{|c|c|c|c|c|c|c|}
\hline Name of material & $\begin{array}{l}\text { elastic shear } \\
\text { modulus } \\
\text { G } \\
{[\mathrm{GPa}]}\end{array}$ & $\begin{array}{l}\text { elastic bulk } \\
\text { modulus } \\
\mathrm{K} \\
{[\mathrm{GPa}]}\end{array}$ & $\begin{array}{l}\text { Young's } \\
\text { modulus } \\
\mathrm{E} \\
{[\mathrm{GPa}]}\end{array}$ & $\begin{array}{l}\text { Cohesion } \\
\mathrm{C} \\
{[\mathrm{MPa}]}\end{array}$ & $\begin{array}{l}\text { Internal } \\
\text { friction } \\
\text { angle } \\
\varphi \\
\left.{ }^{\circ}\right]\end{array}$ & $\begin{array}{l}\text { Tensile } \\
\text { strength } \\
\mathrm{Rr} \\
{[\mathrm{MPa}]}\end{array}$ \\
\hline marly claystone & 0.11 & 0.25 & 0.30 & 2.50 & 35 & 0.50 \\
\hline $\begin{array}{l}\text { argillous-gypsum } \\
\text { buffer zone }\end{array}$ & 0.20 & 0.27 & 0.50 & 0.1 & 20 & 0.1 \\
\hline Quaternary & 0.04 & 0.07 & 0.1 & 0.02 & 30 & 0.01 \\
\hline
\end{tabular}

directions to these walls. These supports were set for the side and bottom walls of the model. The upper wall, reflecting the surface of the terrain, remained free.

For the individual layers constituting the model, a plastic-elastic constitutive model with the Coulomb-Mohr strength criterion was adopted, which was defined by the parameters listed in Table 1. The material properties for the model were adopted on the basis of data provided by the Wieliczka salt mine.

The first stage of the simulation determined the original stress state generated by the volumetric weight of the materials constituting the model. The obtained stress state has generated compressive stress in the vicinity of level IV with the values of $4.17 \mathrm{MPa}$ in the vertical direction and $1.78 \mathrm{MPa}$ in the horizontal plane.

In the second stage, after establishing the original state, the stress and deformation state induced by the creation of the shaft has been mapped. For this purpose, the elements constituting the model inside the shaft contours were assigned a "null" type model, mapping the lack of material, and then balanced, allowing for deformations in the elastic range. The next stage of the simulation involved the introduction of shaft lining defined by a plastic-elastic constitutive model with Coulomb-Mohr strength criterion with the following parameters: shear modulus $0.12 \mathrm{GPa}$, bulk modulus $0.25 \mathrm{GPa}$, cohesion $5 \mathrm{MPa}$, internal friction angle $45^{\circ}$, tensile strength $3 \mathrm{MPa}$.

After introducing the shaft lining and restarting calculations, the model has been balanced. The stress and deformation state obtained in this way was assumed as the initial one for further analysis of the rock mass behaviour in the vicinity of the "Regis" shaft and the "Kloski" chamber.

At this stage, the modelled rock mass is fully stable and only elements located on the sidewalls of the lower part of the shaft, below level IV, have been plasticised (Figure 4).

The main problem in maintaining the stability of the "Regis" shaft and the rock mass that surrounds it is the impact of the post-mining void created after the extraction of a salt block and creation of the "Kloski" chamber. This chamber is one of the largest chambers in terms of cubature in the Wieliczka salt mine and it significantly affects the state of both the rock mass surrounding it and the "Regis" shaft located in its vicinity. 


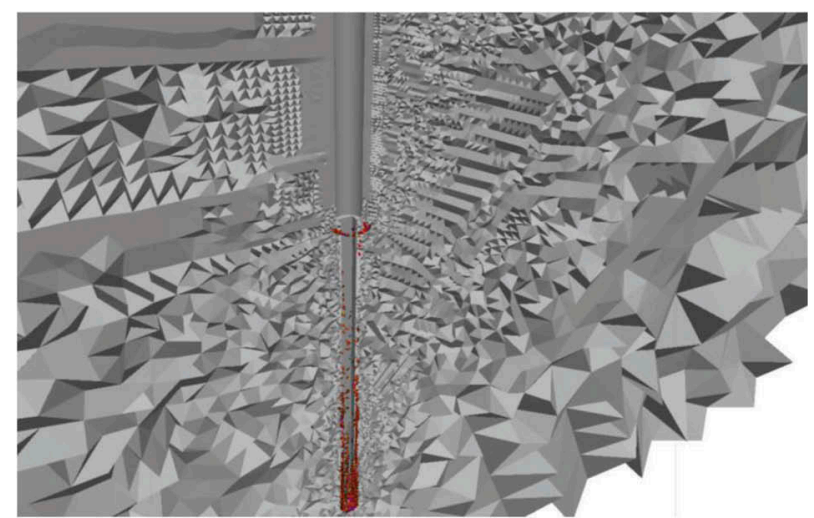

Figure 4. Plasticisation zones in the area of the modelled shaft before excavating the "Kloski" chamber.

\subsection{The model reflecting the current state}

The fundamental stage of modelling involved obtaining by the model the state that corresponded to the current situation by simulating the exploitation of the "Kloski" chamber and introducing a substitute material, representing its filling (wooden mesh cribs, wooden props, barren rock, and sand). For the material filling the chamber, a linear-elastic material was adopted, characterised by deformation parameters reduced a hundred times in relation to the parameters adopted for marly claystone. For the model prepared in this way, after its stabilisation, the modelling stage was reached, reflecting the current deformation and stress state of the rock mass in the vicinity of the "Regis" shaft and the "Kloski" chamber.

When analysing the plasticisation zones in the surroundings of the "Regis" shaft, at this stage of calculations two areas where the model has plasticised can be distinguished (Figure 5).

The first area includes both the rock mass and the modelled shaft supports and reaches from level IV to a depth of about $133 \mathrm{~m}$. The plasticisation of the material in this area can be

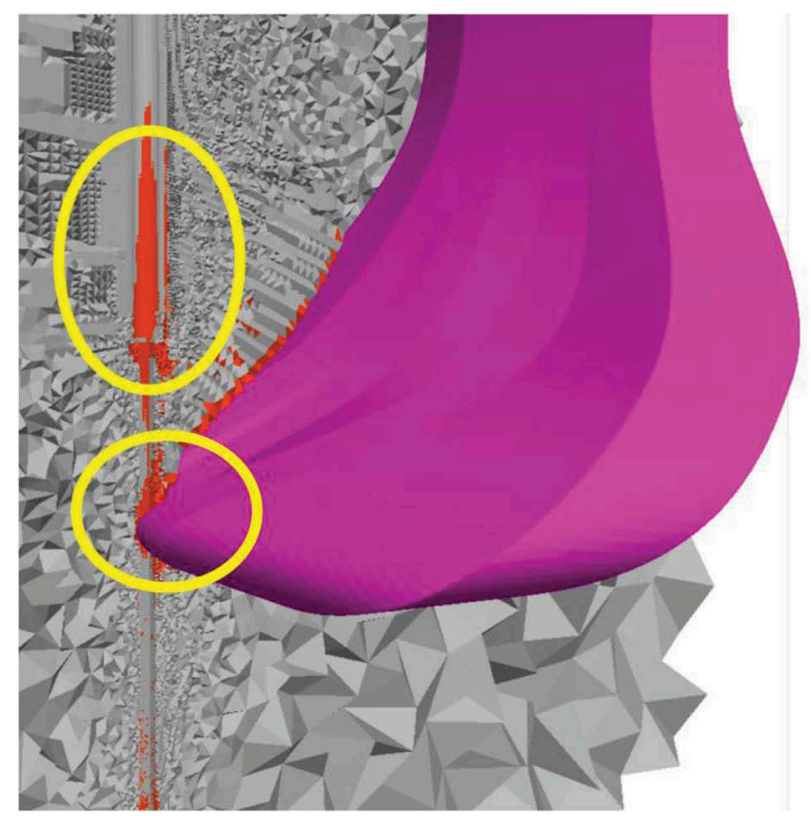

Figure 5. The model plasticisation zones in the vicinity of the "Regis" shaft. 

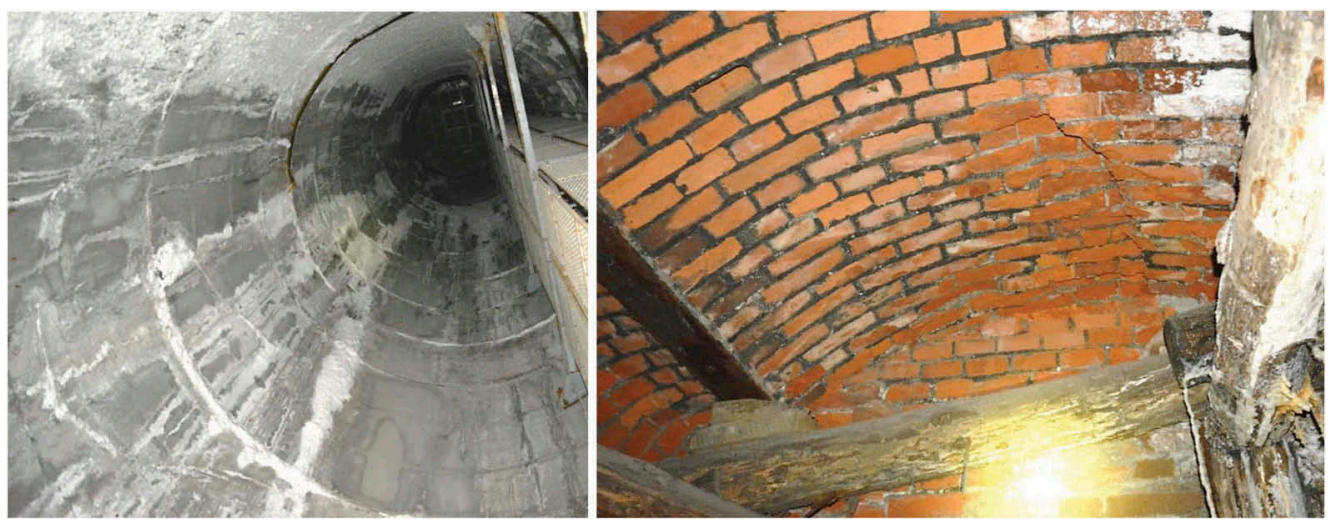

Figure 6. Damage to the shaft lining and shaft bottom supports occurring in the vicinity of the level IV.

equated with the damage observed on the supports in the shaft and shaft bottom at level IV (Figure 6).

The second area includes the rock mass in the area where the shaft crosses the "Kloski" chamber at the depth of level $\mathrm{V}$, where the rock mass around the entire shaft has been damaged, over a section of about $10 \mathrm{~m}$.

The occurrence of plasticisation zones in the model can be interpreted in relation to the actual rock mass as its destruction zones manifesting in the fracturing of rocks and excessive load exerted on the supports leading to scratches and fractures.

The plasticisation zones of the model also occur at a greater distance from the shaft, in the ceiling of the lower part of the "Kloski" chamber, and their range usually amounts to about $1 \mathrm{~m}$. Only in the central part of the chamber a plasticisation zone was created, reaching about $15 \mathrm{~m}$ from the chamber ceiling.

\subsection{The model representing the final state}

The purpose of the simulations was to assess the rock mass stability in the vicinity of the "Regis" shaft over a long time horizon and its impact on the behaviour of the working supports. In order to achieve that, it was assumed that with the passage of time and due to the long-term impact of environmental factors, the rock mass mechanical parameters in the plasticisation zones will be subjected to gradual degradation. This phenomenon was modelled by adopting a plastic-elastic constitutive model with weakening, characterised by a total reduction of cohesion and tensile strength in the plasticised elements. This solution has also been used in numerous geomechanical analyses, the results of which have been presented, for example, in Diao et al. 2016, Badr et al. 2003, Szafulera and Jendryś 2012, Reymany and Vakili 2017. It was also assumed that the material filling the "Kloski" chamber will consolidate over time, which was reflected in the model by reducing the stress in the material filling the post-mining void.

The above operations caused further chamber clamping as well as deformations and destruction of the rock mass in the vicinity of the "Regis" shaft. As a result, after the equilibration of the model, its final state was obtained. The results in the form of plasticisation zones and displacement distributions are presented in Figure 7 and Figure 8.

The largest displacements of the rock mass around the "Regis" shaft occurred at the depth of level V (Figure 7). In this location, a large plasticisation zone has formed, resulting in the material undergoing plastic flow, and the displacements would mainly approach a horizontal direction at values exceeding $1.5 \mathrm{~m}$. In the area of level IV, the displacements of the model towards the chamber amounted to $0.53 \mathrm{~m}$.

The obtained results of the plasticisation zones (Figure 8) for the final model indicate a significant increase in the damage zones in relation to the model representing the current 


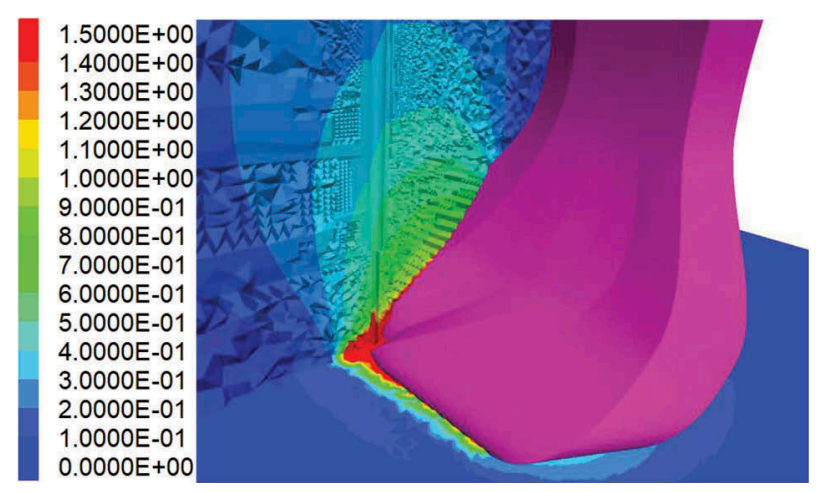

Figure 7. Displacements in the modelled rock mass - final state of the model, vertical cross-section through the shaft in a north-south direction, level V at a depth of $196 \mathrm{~m}$.

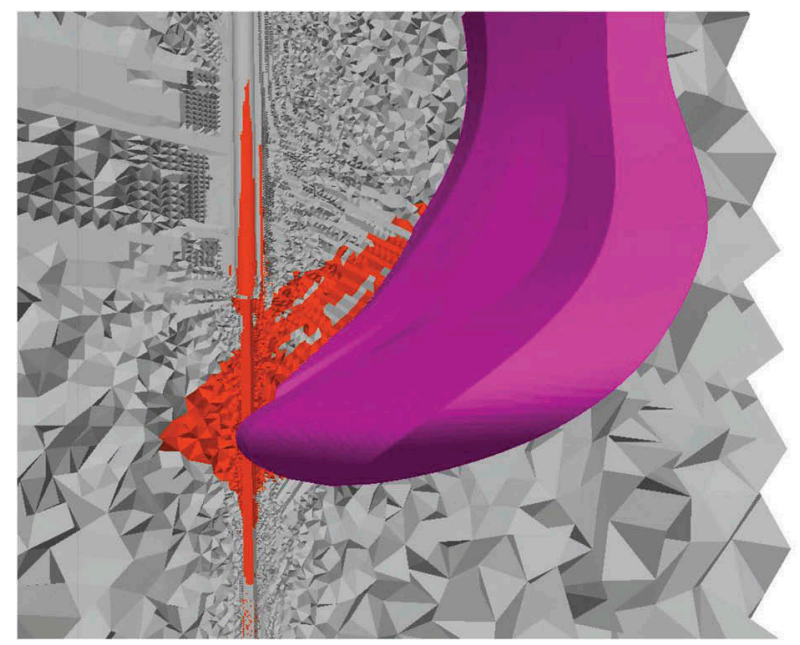

Figure 8. Plasticisation zones for the variant representing the final state of the rock mass, vertical section through the shaft in a north-south direction, plasticised elements marked in red.

state. These zones reach to about $15 \mathrm{~m}$ above the chamber ceiling and cover the entire section of the shaft between levels V and IV. In this model, at level V depth, the plasticisation zone in the shaft vicinity extends over a distance of over $15 \mathrm{~m}$ deep into the rock mass on the side opposite to the "Kloski" chamber.

According to the simulations carried out, a large volume of the rock mass in the area of the level IV was also damaged, and the plasticisation of shaft supports reaches to a depth of $125 \mathrm{~m}$.

In the area of level IV, cribwork was created to ensure the carrying capacity of the shaft section constructed above. The destruction of the rock mass in this area may result in the displacement of rock rubble into the shaft below level IV, the lack of cribwork foundation, and, as a result, a large displacement and destruction of the "Regis" shaft supports, also above level IV.

\subsection{The target model taking into account the backfilling of the "Kloski" chamber and sections of the "Regis" shaft}

As the presented calculations demonstrated, leaving the rock mass in the area of the "Kloski" chamber without any protective works may pose a threat to its stability and the stability of the "Regis" shaft lining, which currently constitutes the main transportation shaft of the Wieliczka salt mine. 
In order to secure the shaft and the rock mass in the vicinity of the "Kloski" chamber, it was proposed to fill the chamber and the shaft below level IV with a liquid self-solidifying mineral injection mixture based on ground blast furnace slag, cement, and brine produced in the Wieliczka mine.

The application of this solution was also analysed in the numerical model by assigning to the elements constituting the model inside the "Kloski" chamber and the "Regis" shaft below level IV the parameters of the elastic medium with a Young's modulus of $3 \mathrm{GPa}$.

This variant was modelled by introducing the backfill material (marked in green in Figure 9) into the model representing the current state and by adopting plastic-elastic material with weakening for the rock mass with identical parameters as during the simulation leading to obtaining the final state of the rock mass without using the filling material.

The resultant displacements obtained in this variant are shown in Figure 10. The obtained results in the form of displacements indicate only a slight increase in rock mass deformation in the analysed model in relation to the variant representing the current state. The maximum displacements in the model taking into account the filling of parts of the chamber and the shaft are only $5 \mathrm{~cm}$ larger than those obtained for the current state and amount to $0.77 \mathrm{~m}$. The displacements in the vicinity of the shaft inlet to level IV amount to about $0.39 \mathrm{~m}$ and are only $3 \mathrm{~cm}$ larger than those occurring in the reference variant.

The results obtained for the model taking into account the reduction of post-destruction parameters (Figure 11, Figure 12) indicate that filling parts of the "Regis" shaft and the "Kloski" chamber will significantly inhibit the propagation of destruction zones. The ranges of the destruction zones in the chamber ceiling, as well as in the area of the shaft inlet remain practically unchanged. The range of the fracture zone in the shaft lining increased by $1 \mathrm{~m}$, and in the analysed variant it reaches the depth of $132 \mathrm{~m}$.

The increase in the plasticisation zones after backfilling the part of the chamber will occur mainly in its lower part at a depth of about $195 \mathrm{~m}$. However, this phenomenon, due to the filling of the chamber, will not pose a threat to the workings situated above.

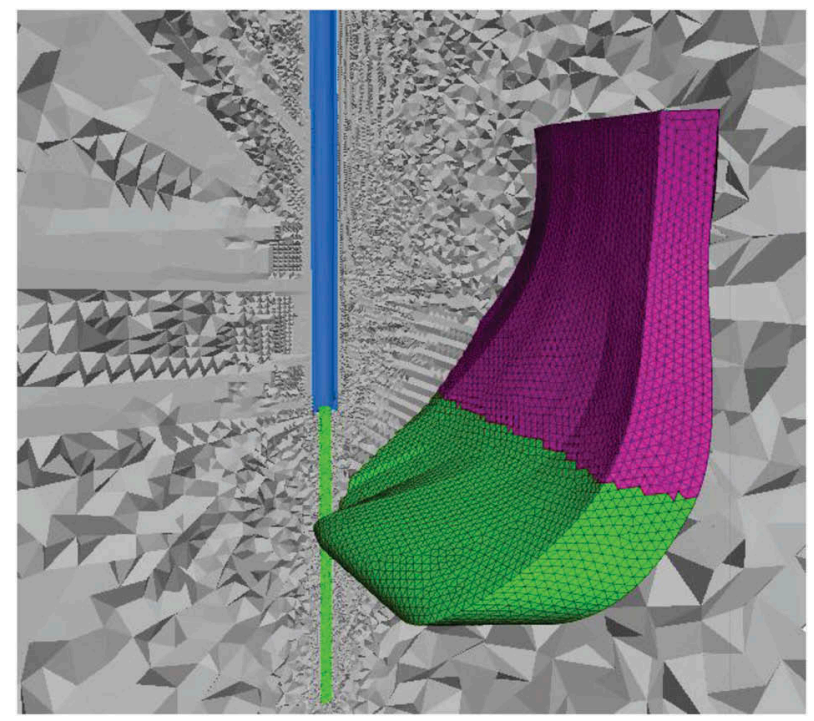

Figure 9. The model taking into account the filling of the shaft and the "Kloski" chamber below level IV (the backfill material is marked in green). 


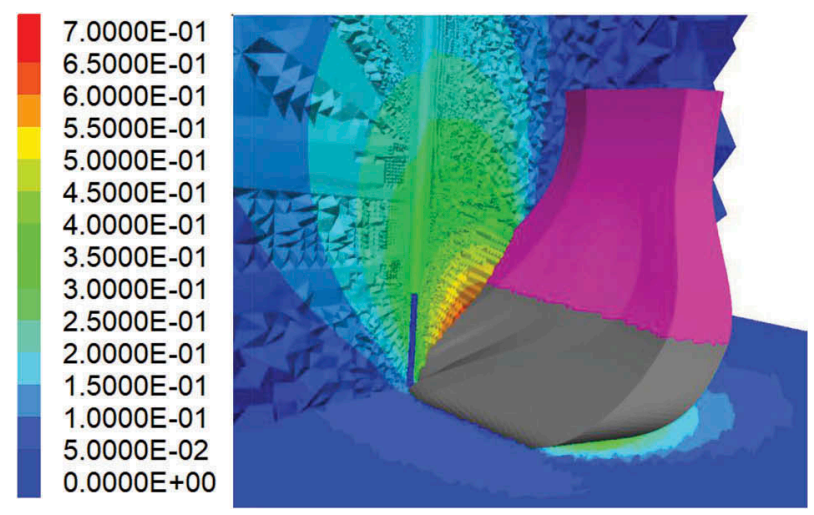

Figure 10. Displacements in the modelled rock mass - the model taking into account the filling of the "Regis" shaft and the "Kloski" chamber below level IV, vertical cross-section through the shaft in the north-south direction, horizontal cross-section at a depth of $196 \mathrm{~m}$.

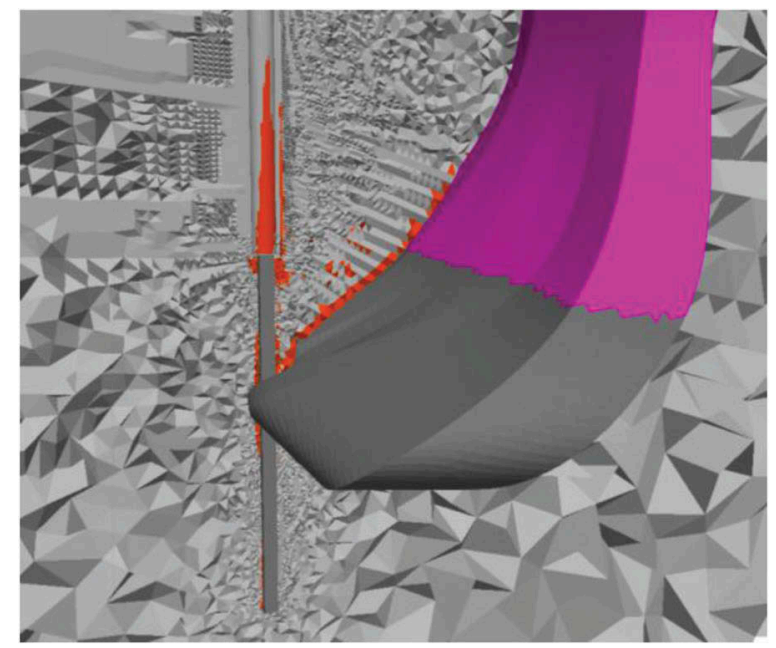

Figure 11. Plasticisation zones for the variant taking into account the filling of the "Regis" shaft and the "Kloski" chamber below level IV, vertical cross-section through the shaft in the north-south direction, plasticised elements marked in red.

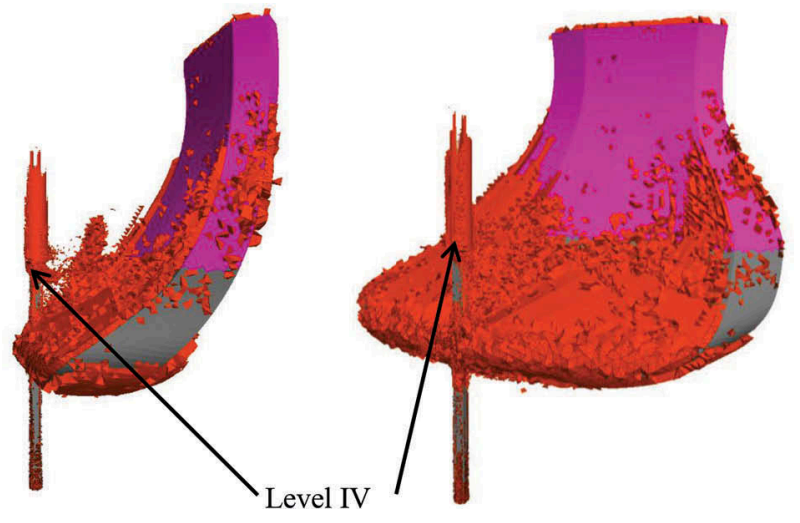

Figure 12. Spatial diagram of the plasticisation zones, the model taking into account the filling of the "Regis" shaft the "Kloski" chamber below level IV, plasticised elements marked in red. 


\section{SUMMARY}

The "Regis" shaft is one of the key workings which ensure the safety and smooth flow of tourist traffic in the historic Wieliczka salt mine. Its fault-free operation requires the monitoring of the technical condition of the supports and the behaviour of the rock mass surrounding the shaft. The results of ongoing geodetic monitoring and macroscopic observations of the shaft supports and adjacent workings indicate a gradual and progressive degradation of the rock mass structure. Such phenomena negatively affect the stability of workings located in this area.

In order to assess the impact of the progressive degradation of the rock mass structure on the shaft and its adjacent workings, a spatial numerical model of the rock mass of the area was created, taking into account its current geomechanical situation, using the FLAC 3D software based on the finite difference method. On the basis of the available documentation and the results of observations and analyses carried out, it was established that the greatest impact on such behaviour of the rock mass in the vicinity of the "Regis" shaft is exerted by a large post-mining chamber, called the "Kloski" chamber, located on the north-east side, in the immediate vicinity of the shaft tube.

In order to map the stress and deformation states and to determine the final state of the rock mass, a constitutive model was adopted, assuming the reduction of post-destruction parameters. Consequently, the results indicating a considerable increase in the plasticisation zone were obtained, especially in the shaft section between levels IV and V. The simulations also indicated a significant increase in rock mass deformation, with the maximum displacements resulting from the plastic flow of the modelled material reaching values exceeding $1.5 \mathrm{~m}$, which occurred in the vicinity of the shaft bottom at level V. This behaviour of the model clearly demonstrates the possibility of the formation of collapses and large displacements threatening the stability of the "Regis" shaft lining. Such a situation may pose a threat to the shaft and adjacent workings in the future, if the appropriate protective works are not undertaken.

Based on the results of calculations and analyses, it was recommended to grout the "Kloski" chamber and fill the "Regis" shaft below level IV. Such solution would stop the propagation of damage zones and minimise the rock mass displacement. Creating a stress and deformation state in the model, achieved as a result of backfilling a part of the shaft and the chamber, is likely to ensure stability and safe operation of the workings located above it, in particular the section of the "Regis" shaft from the surface to level IV.

\section{ACKNOWLEDGMENTS}

"The author - Patrycja Jarczyk - also expresses gratitude to the National Agency for Academic Exchange of Poland (under the Academic International Partnerships program, grant agreement PPI/APM/2018/1/00004) for financial support of the internship at Montanuniversität in Leoben, Austria which enabled the execution of a part of the work".

\section{BIBLIOGRAPHY}

Badr, S., Ozbay, U., Kieffer, S. \& Salamon, M. 2003. Three-Dimensional Strain Softening Modeling of Deep Longwall Coal Mine Layouts. In: Brummer et al. (eds.) FLAC and Numerical Modeling in Geomechanics. Swets \& Zeitlinger, Lisse”: 233-239.

Bruneau, G., Tyler, DB., Hadjigeorgiou, J. \& Potvin, Y. 2003. Influence of faulting on a mine shaft-a case study: part I-Background and instrumentation. Int. J. Rock Mech. Min. Sci. 40: 95-111.

Cała, M., Czaja, P., Flisiak, D. \& Kowalski, M. 2009. Ocena zagrożenia zapadliskowego wybranych komór KS „Wieliczka” w oparciu o obliczenia numeryczne. Górnictwo i Geoinżynieria Vol. 3/1: 33-44.

Cała, M., Stopkowicz, A., Kowalski, M., Blajer, M., Cyran, K. \& D’Obyrn, K. 2016. Stability analysis of underground mining openings with complex geometry. Studia Geotechnica Et Mechanica, Vol. 38, No. 1: 25-32. https://doi.org/10.1515/Sgem-2016-0003. 
Chudek, M., Kleta, H., Wojtusiak, A. \& Chudek, MD. 2009. Obudowa szybów w warunkach znacznych ciśnień deformacyjnych górotworu. Górnictwo i Geoinżynieria Vol. 3/1: 87-90.

Cieślik, J., Flisiak, J. \& Tajduś, A. 2009. Analiza warunków stateczności wybranych komór KS „Wieliczka" na podstawie przestrzennych obliczeń numerycznych. Górnictwo i Geoinżynieria Vol. 3/1: 91-103.

D’Obyrn, K. and Wiewiórka, W. 2015. Renowacja górnicza komory Jezioro Wessel na poziomie III Kopalni Soli,Wieliczka” S.A. Przegląd górniczy No. 7: 69-77.

Diao, XH., Yang, SX. \& Wang, K. 2016. Application of strain softening model to numerical analysis of deep tunnel. In: Kim (ed.) Progress in Civil, Architectural and Hydraulic Engineering IV. Taylor \& Francis Group, London: 373-378.

Kleta, H. and Jendryś, M. 2013. Przyczyny uszkodzeń obudowy w głębionym szybie w świetle obliczeń numerycznych, Bud. Gór. Tunelowe No. 3: 1-8.

Kortas, G. 2010. Szyb z obudową w górotworze solnym — wstępne badania modelowe, Górnictwo i Geoinżynieria Vol. 2: 395-403.

Kwinta, A. 2012. Prediction of strain in a shaft caused by underground mining. Int. J. Rock Mech. Min. Sci. 55: 28-32.

Majcherczyk, T. and Lubryka, M. 2003. The influence of the depth of an exploited seam on stresses around the shaft, Archives of Mining Sciences 48: 65-80.

Rajmeny, PK. and Vakili, A. 2017. Three-dimensional inelastic numerical back-analysis of observed rock mass response to mining in an Indian mine under high-stress conditions. In Wesseloo (ed.) Deep Mining 2017: Eighth International Conference on Deep and High Stress Mining, Perth: 329-342.

Szafulera, K. and Jendryś, M. 2012. Numeryczna analiza stanu odkształcenia górotworu w sąsiedztwie płytkich wyrobisk porudnych. Górnictwo i Geologia Vol. 7 No. 1: 187-199.

Tajduś, A., Cała, M., Flisiak, J. \& Lubryka, M. 2003. Ocena możliwości częściowego naruszania filarów ochronnych szybów na podstawie obliczeń numerycznych stanu naprężenia w otoczeniu rury szybowej, Górnictwo i Geoinżynieria Vol. 3-4: 601-613.

Wanga, JA., Park, HD. \& Gaoa, YT. 2003. A new technique for repairing and controlling large-scale collapse in the main transportation shaft, Chengchao iron mine, China, Int. J. Rock Mech. Min. Sci. 40: 553-563. 